\title{
A Synthetic Tumor Necrosis Factor-a Agonist Peptide Enhances Human Polymorphonuclear Leukocyte-mediated Killing of Plasmodium falciparum In Vitro and Suppresses Plasmodium chabaudi Infection in Mice
}

\author{
Lakshmi M. Kumaratilake, *‡ Deborah A. Rathjen, *5 Philip Mack, ${ }^{5}$ Fred Widmer, ${ }^{5}$ Varee Prasertsiriroj," \\ and Antonio Ferrante* \\ *Department of Immunology and ${ }^{\ddagger}$ Department of Paediatrics (University of Adelaide), Women's and Children's Hospital, Adelaide, \\ South Australia 5006, Australia; 8 Peptide Technology Ltd., Dee Why, New South Wales 2099, Australia; and "Mahidol University, \\ Bangkok, Thailand
}

\begin{abstract}
A peptide corresponding to residues 70-80 of the TNF- $\alpha$ polypeptide was synthesized and shown to enhance human PMN-mediated killing of Plasmodium falciparum in vitro and reduced the Plasmodium chabaudi parasitemia in mice. Studies of the mechanism of action showed that the peptide, TNF ${ }_{(70-80)}$, stimulated and primed PMN for an increased respiratory burst and release of granule constituents in response to a second agonist. The PMN-stimulatory activity of the peptide was inhibited by mAbs against the p55 and p75 TNF receptors and a TNF-neutralizing mAb. Analysis of PMN receptor expression showed that CR3 (CD18/ CD11b) and Fc $\gamma$ RIII were upregulated by TNF ${ }_{(70-80)}$, which was consistent with the peptide's ability to enhance parasite killing by PMN. The peptide, unlike TNF, did not increase the expression of adhesion molecules on endothelial cells and failed to promote binding of $P$. falciparum-infected erythrocytes to endothelial cells. TNF ${ }_{(70-80)}$ also inhibited the TNF-induced increase in adhesion of $P$. falciparum-infected erythrocytes to endothelial cells. The results demonstrate that the host-protective effects of TNF can be retained while toxic effects are eliminated using a selected, characterized subunit of the cytokine. (J. Clin. Invest. 1995. 95:23152323.) Key words: malaria - neutrophils • endothelium • adhesion inhibition
\end{abstract}

Portions of this paper were presented at the Fifth International TNF Congress in Monterey, California, June 1994.

Address correspondence to Dr. L. M. Kumaratilake, Department of Paediatrics, Women's and Children's Hospital, North Adelaide, South Australia 5006, Australia. Phone: 8-204-6337; FAX: 8-204-6046.

Received for publication 1 October 1994 and in revised form 27 December 1995.

1. Abbreviations used in this paper: CL, chemiluminescence; ELAM1, endothelial leukocyte adhesion molecule 1; HBSS-A, HBSS supplemented with $0.1 \%$ HSA; HNS, heat-inactivated normal serum; HUVEC, human umbilical vein endothelial cells; ICAM-1, intercellular adhesion molecule 1; IRBC, Plasmodium falciparum-infected red blood cells; IS, immune serum; NS, normal serum; RBC, red blood cells; TNF $_{(70-80)}$, synthetic TNF peptide; TNFR, TNF receptor; VCAM-1, vascular cell adhesion molecule 1 .

J. Clin. Invest.

(C) The American Society for Clinical Investigation, Inc. 0021-9738/95/05/2315/09 \$2.00

Volume 95, May 1995, 2315-2323

\section{Introduction}

TNF is a pleotropic, proinflammatory cytokine with effects on a variety of cells. Many studies (1-8), including those on TNF receptor (TNFR) ${ }^{1}$ (p55) gene knockout mice $(9)$, have shown that TNF plays an important role in defense against infections. It stimulates and primes neutrophils for enhanced oxygen radical production $(5,10-13)$, degranulation $(6,11,13)$, and associated microbicidal and tumoricidal activities (1-7). In malaria, phagocytic cell-mediated killing of the parasite constitutes a major part of the protective immunity against the asexual blood stages $(6,14-16)$. We have previously shown that TNF and its structurally related lymphokine, lymphotoxin, enhance the human neutrophil-mediated killing of Plasmodium falciparum asexual intraerythrocytic stage $(17,18)$ and merozoites (19). While TNF plays an important role in microbial immunity, it is also known to be a mediator of pathophysiology associated with a variety of infections and autoimmune inflammatory diseases $(1,2,20,21)$. In P. falciparum infections, TNF is believed to play a crucial role in the pathogenesis of cerebral malaria (22), which causes $\sim 20 \%$ mortality despite treatment with antimalarial drugs (23). The toxic effects of the cytokine limit its application as a chemotherapeutic or immunoregulatory agent $(1,2,24,25)$.

From a recently described region of the TNF molecule that possesses neutrophil-stimulatory properties $(26)$, it has been possible to derive a soluble 11-mer peptide that has high stability in serum. Characterization of its biological properties showed that the peptide primed neutrophils for enhanced killing of $P$. falciparum and significantly reduced the Plasmodium chabaudi parasitemia in mice. The peptide was found to prime neutrophils for increased release of oxygen-derived reactive species and degranulation, and it upregulated the expression of CR3 and Fc $\gamma$ III receptors. The action of the peptide appeared to be via the TNF receptors. In contrast to TNF, the synthetic peptide failed to promote the sequestration of $P$. falciparum schizonts and trophozoite-infected erythrocytes to human endothelial cells. Thus $\operatorname{TNF}_{(70-80)}$ appears to show substantial selectivity in inducing host-protective responses.

\section{Methods}

\section{Peptide synthesis}

The peptide $\mathrm{TNF}_{(70-80)}$, derived from the primary amino acid sequence of human TNF ( see Fig. 1), was prepared by the F-moc-polyamine (27) method of solid phase peptide synthesis using the PepSyn KA solid resin (Cambridge Research Biochemical Ltd., Cambridge, United Kingdom) (28). The sequence from the natural TNF was modified by substitution of isoleucine for leucine at position 76 (see Fig. 1). The modification extended the serum half-life of the peptide to $>90 \mathrm{~min}$ 
A

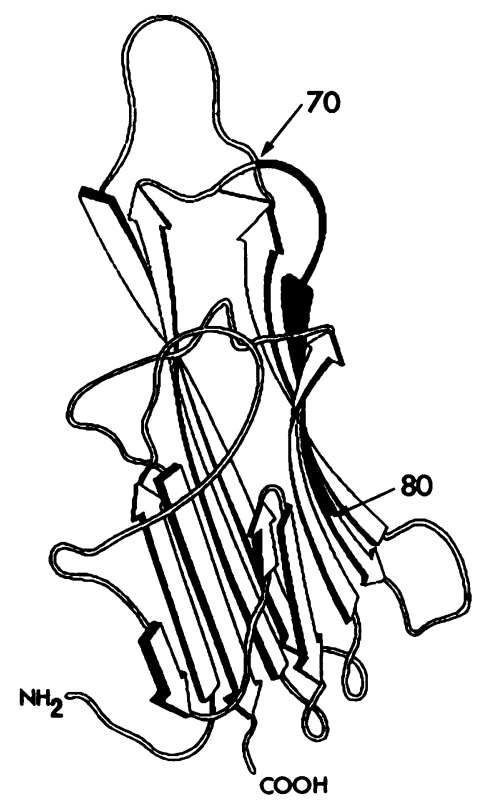

B

H-Pro - Ser - Thr - His - Val - Leu - Ilou - Thr - His - Thr - Hou -OH

Figure 1. (A) TNF monomer showing the position of peptide $\operatorname{TNF}_{(70-80)}$ at 70-80 from the distal end of the molecule. $(B)$ Amino acid sequence of peptide $\mathrm{TNF}_{(70-80)}$ indicating the isoleucine substitution (bold).

and increased water solubility (data not shown). A peptide, code 205, with the sequence H-Gly-Gly-Asp-Pro-Gly-ILe-Val-Thr-His-Ser-OH was used as a negative control. Fresh dilutions of the peptides were prepared daily in HBSS containing $0.1 \%$ human group $A B$ heat-inactivated $\left(56^{\circ} \mathrm{C}, 30 \mathrm{~min}\right)$ sera. These preparations contained $<0.1 \mathrm{LPS} \mathrm{U} /$ $\mathrm{ml}$ as determined by the limulus amebocyte lysate assay.

\section{Cytokines}

Human recombinant TNF (99\% purity) was produced by Genentech, Inc. (San Francisco, CA) and kindly provided by Dr. G. R. Adolf (ErnstBoehringer Ingelheim Institut, Vienna, Austria). This preparation had a specific activity of $6 \times 10^{7} \mathrm{U} / \mathrm{mg}$ assayed for cytotoxicity by the supplier on actinomycin-D-treated murine fibrosarcoma cell line L929. The preparation was $>98 \%$ pure, and LPS contamination was $<0.125$ LPS U/ml (by limulus amebocyte lysate assay). Fresh dilutions of TNF were prepared daily in HBSS containing $0.1 \%$ heat-inactivated $\left(56^{\circ} \mathrm{C}\right.$, $30 \mathrm{~min}$ ) human group $\mathrm{AB}$ sera. These preparations contained $<0.1$ LPS U/ml.

\section{Antibodies}

The preparations of affinity-purified human anti-human TNFR mAb utr 1 (directed against human TNFR, p75) and mAb htr 9 (against human TNFR, p55) were provided by Dr. M. Brockhaus (Hoffman-La Roche, Ltd; Basel, Switzerland). TNF-neutralizing mAb (mAb 54) against human TNF was prepared as described previously (29). The following mAbs were purchased: anti-human intercellular adhesion molecule 1 (ICAM-1) (Immunotech, Marseille, France), anti-human endothelial leukocyte adhesion molecule 1 (ELAM-1) (E-selectin) and vascular cell adhesion molecule 1 (VCAM-1) (Becton Dickinson and Co., San Jose, CA), and horseradish peroxidase-conjugated rabbit immunoglobulin (Dakopatts, Copenhagen, Denmark) anti-CD 11c (KB90, IgG1 ) malaria.

\section{Reagents}

RPMI 1640, medium 199, and gelatin were purchased from Cytosystem Pty, Ltd. (Castle Hill, Australia); $\left[{ }^{3} \mathrm{H}\right]$ hypoxanthine and cyano- $\left[{ }^{57} \mathrm{Co}\right]$ - cobalamin were from Amersham Corp. (Arlington Heights, IL); Triton X-100 was from Ajax Chemicals Proprietary, Ltd. (Sydney, Australia); 4-methylumbelliferyl-b-D-glucuronide was from Boehringer Mannheim GmbH (Mannheim, FRG); and D-glucose, activated charcoal (Norit GSX), and Giemsa (Gurr) were from BDH Chemicals (Victoria, Australia). $N$-tris(hydroxymethyl) methyl-2-aminoethane-sulfonic acid (TES buffer), 2,2'-azinobis(3-ethylbenzthiazoline sulfonic acid) (ABTS), 5-amino-2,3-dihydro-1,4-phthalazinedione (luminol), bis- $N$ methylacridinium nitrate (lucigenin), cytochrome $\mathrm{C}$, superoxide dismutase, HSA, glycine, and FMLP were obtained from Sigma Chemical Co. (St. Louis, MO). All reagents were prepared in pyrogen-free diluents and stored according to the manufactures' instructions.

\section{$P M N$ preparation and treatment with $T N F$ or $T N F_{(70-80)}$}

PMN were prepared from peripheral blood of healthy donors by the rapid single-step technique using Hypaque-Ficoll (Hypaque from Schering AG, Berlin, Germany and Ficoll from Pharmacia LKB Biotechnology, Uppsala, Sweden) medium $(d=1.114)(30)$. These cells were $>99 \%$ viable and $>96 \%$ pure $(\sim 0.2-4 \%$ eosinophils, $0-0.5 \%$ mononuclear cells). PMN were suspended in medium 199 at $2 \times 10^{7} / \mathrm{ml}$. PMN $(50 \mu \mathrm{l})$ were normally pretreated with $50 \mu \mathrm{l}$ of $\mathrm{TNF}_{(70-80)}$, the control peptide, diluent (HBSS containing $0.1 \% \mathrm{HNS}$ ), and the positive control, TNF (100-200 U), at $37^{\circ} \mathrm{C}$ for $30 \mathrm{~min}$. A range of peptide concentrations $(0.01,1,2,5,10,100$, and $300 \mu \mathrm{g})$ were normally used in preliminary experiments, and optimum concentrations are given under specific methods.

\section{Parasite}

In vitro studies were carried out using human malaria species, $P$. falciparum. Four isolates of the parasite either collected from malaria-infected individuals in Papua New Guinea or from those who migrated from there to Australia were maintained in group $\mathrm{O}^{+}$human red blood cells (RBC) in RPMI 1640 medium (supplemented with 10\% heatinactivated group $\mathrm{AB}^{+}$serum, $0.25 \% \mathrm{D}$-glucose, and $0.85 \%$ TES buffer) in tissue culture flasks $\left(75 \mathrm{~cm}^{2}\right.$; Corning Inc., Corning, NY) that were gassed with $1 \% \mathrm{O}_{2}$ and $5 \% \mathrm{CO}_{2}$ in $\mathrm{N}_{2}$ at $37^{\circ} \mathrm{C}(18)$. Three of the four isolates used possessed knobs. The experiments were conducted either with nonsynchronized cultures at $10^{8} \mathrm{RBC} / \mathrm{ml}$ with $3-5 \%$ parasitemia $(17,18)$ or with purified trophozoite and schizont stages $(31)$.

Plasmodium chabaudi-infected mouse RBC stored under liquid $\mathrm{N}_{2}$ were used to initiate infections in mice. When the parasitemia reached $\sim 10 \%$, blood was taken from the retroorbital plexus, washed once in normal saline $\left(0.9 \%\right.$ sodium chloride), adjusted to $2 \times 10^{6} \mathrm{RBC} / \mathrm{ml}$, and used for in vivo studies.

\section{Sera}

Immune serum (IS) refers to serum or plasma obtained from individuals who were long-term residents in malaria-endemic areas in Papua New Guinea or the Solomon Islands. These sera contained high titers of anti$P$. falciparum antibody and $<10$ hemolytic units of complement (19).

NS was obtained from healthy Australians (group AB) who had not been exposed to malaria. These samples contained $104 \pm 15$ hemolytic units of complement and no antimalarial antibody. A portion of NS was heat inactivated at $56^{\circ} \mathrm{C}$ for $30 \mathrm{~min}$.

\section{$P$. falciparum growth inhibition assay}

The in vitro growth inhibition of $P$. falciparum was quantified by a previously established radiometric assay $(17,18)$. After the pretreatment of PMN with $\mathrm{TNF}_{(70-80)}$, control peptide, or diluent, they were mixed with $50 \mu \mathrm{l}$ of $P$. falciparum culture (RBC $5 \times 10^{6}$ with 3-5\% parasitemia) and $50 \mu \mathrm{l}$ of sera (IS, NS, or HNS) in 96-well microdilution plates. The direct effects of the peptide or TNF were also studied by adding these to the parasites in the absence of PMN. The plates were incubated for $2 \mathrm{~h}$ at $37^{\circ} \mathrm{C}$ in $5 \% \mathrm{CO}_{2}$, and $\left[{ }^{3} \mathrm{H}\right]$ hypoxanthine $(1 \mu \mathrm{Ci})$ was added into the wells. The plates were incubated for a further $18 \mathrm{~h}$ at $37^{\circ} \mathrm{C}$ in $5 \% \mathrm{CO}_{2}$, during which time the parasites took up $\left[{ }^{3} \mathrm{H}\right]-$ hypoxanthine but PMN took up negligible amounts of the label. Individual well contents were collected using a semiautomated cell harvester, 
and the uptake of $\left[{ }^{3} \mathrm{H}\right]$ hypoxanthine was measured in a liquid scintillation counter (LS 3801; Beckman Instruments, Carlsbad, CA).

Percent inhibition of growth of the parasite was calculated by the following formula: percent inhibition $=(\mathrm{dpm}$ of parasite $)-(\mathrm{dpm}$ of parasite mixed with $\mathrm{PMN}) \times 100 /(\mathrm{dpm}$ of parasite $)$. Percent inhibition of the parasite due to direct effects of TNF or the peptides was calculated as follows: percent inhibition $=(\mathrm{dpm}$ of parasite $)-(\mathrm{dpm}$ of parasite mixed with either TNF, TNF $_{(70-80)}$, or HBSS $) \times 100 /($ dpm of parasite $)$.

\section{Light microscopic examinations}

Cytocentrifuge smears were prepared from the well contents (run in parallel to the radiometric assay) after $18 \mathrm{~h}$ of incubation and stained with Giemsa. They were examined at a magnification of 1,000 for the following, without generating quantitative data: PMN morphological integrity (when a PMN is rounded off, smaller in size with dense, round nucleus without the typical polymorphous nature, considered as morphologically abnormal), parasite morphology (when the parasite nucleus becomes dense without demarcation from cytoplasm, without typical characteristics of the parasite, considered as degenerated), binding of $P$. falciparum-infected RBC (IRBC) to PMN, evidence for ingested parasites by PMN, and evidence for killing and digestion of the parasites inside PMN (17-18).

\section{Measurement of $P$. falciparum-IRBC adherence to human umbilical vein endothelial cells (HUVEC)}

Morphological studies. Endothelial cells were cultured in RPMI 1640 supplemented with $20 \%$ NS (32). At the time of the first subculture, cells $\left(5 \times 10^{4}\right)$ were transferred into each well of gelatin $(0.1 \%)$ coated 8-well chamber slides (Lab-Tek; Naperville, IL), and $400 \mu \mathrm{l}$ of RPMI 1640 (supplemented with 20\% HNS) was added. When the endothelial cells were confluent, the wells were washed with HBSS supplemented with $0.1 \%$ HSA (HBSS-A). Either $200 \mu \mathrm{l}$ of TNF (200 $\mathrm{U}), \mathrm{TNF}_{(70-80)}(200 \mu \mathrm{g})$, control peptide $(200 \mu \mathrm{g})$, or diluent was added into the wells and incubated normally for $1 \mathrm{~h}$ at $37^{\circ} \mathrm{C}$. After the incubation, $100 \mu \mathrm{l}$ of the supernatants was removed, replaced with purified (30) knob-positive $P$. falciparum $\left(3 \times 10^{5} \mathrm{IRBC}\right.$, containing $>90 \%$ trophozoites and schizonts), and incubated for $30 \mathrm{~min}$ at $37^{\circ} \mathrm{C}$ in $5 \% \mathrm{CO}_{2}$ in air. The wells were washed three times with HBSS-A to remove nonbound $\mathrm{RBC}$. The cells were fixed in methanol and stained with Giemsa. The number of IRBC adhered to 1,500 HUVEC was counted from each well, at a magnification of 1,000 . The results were expressed as the number of IRBC adhered to 100 endothelial cells.

Radiometric quantification of IRBC adherence. Purified trophozoite and schizonts (90-98\% purity) of knob-positive $P$. falciparum in malaria culture medium (free of serum) were mixed with $\left[{ }^{3} \mathrm{H}\right]-$ hypoxanthine at $1 \mu \mathrm{Ci} / 10^{6} \mathrm{IRBC}$, gassed with $1 \% \mathrm{O}_{2}$ and $5 \% \mathrm{CO}_{2}$ in $\mathrm{N}_{2}$, and maintained at $37^{\circ} \mathrm{C}$ for $4 \mathrm{~h}$. The medium was removed, and RBC were washed twice with HBSS by centrifugation. IRBC pellet was reconstituted at $5 \times 10^{4} / 100 \mu \mathrm{l}$ in HBSS containing $20 \%$ NS.

Endothelial cells were cultured at $5 \times 10^{5} /$ well in 96 -well microdilution plates. When confluent, they were washed twice with HBSS-A and mixed with either $200 \mu \mathrm{l}$ of TNF (200 U), $\operatorname{TNF}_{(70-80)}(200 \mu \mathrm{g})$, control peptide ( $200 \mu \mathrm{g})$, or diluent. In some experiments where TNF-inhibitory activities of $\mathrm{TNF}_{(70-80)}$ were studied, the peptide and the cytokine (at the above concentrations) were mixed at $1: 1(\mathrm{vol} / \mathrm{vol})$ before adding $200-\mu \mathrm{l} \mathrm{vol}$ into the wells. The plates were incubated for $1 \mathrm{~h}$. From the wells, $100 \mu \mathrm{l}$ of the supernatant was removed and replaced with 100 $\mu$ l of IRBC $\left(5 \times 10^{4} /\right.$ well $)$. In addition, the parasite $\left(5 \times 10^{4} \mathrm{IRBC} /\right.$ well) was maintained in six separate wells in the absence of HUVEC, while six wells of HUVEC received HBSS-A without any other treatment. The plates were incubated for $30 \mathrm{~min}$ at $37^{\circ} \mathrm{C}$ in $5 \% \mathrm{CO}_{2}$. The wells containing HUVEC were washed with HBSS-A three times. To lyse erythrocytes, distilled water $(150 \mu \mathrm{l} /$ well $)$ was added to those wells that contained IRBC (with or without HUVEC). The supernatants were collected into vials containing liquid scintillant $(3.8 \mathrm{ml})$, and the amount of $\left[{ }^{3} \mathrm{H}\right]$ hypoxanthine was measured using a $\beta$-counter (LS 3801; Beckman Instruments).

The percentage of mature parasites $(A)$ was counted using Giemsa- stained thin smears prepared from the cultures (with known RBC number) at the beginning of the experiment. The number of HUVEC per well $(B)$ was determined by adding $0.1 \%$ trypsin into the wells and counting the endothelial cells using a hemocytometer.

The number of IRBC adhered on 100 HUVEC $=[(A) \times(d p m$ due to adhered IRBC on HUVEC $)] \times 100 /[(B) \times(d p m$ of IRBC $)]$.

Effects of peptide $T N F_{(70-80)}$ in $P$. chabaudi-infected mice 6-8-wk-old female BALB/c mice were infected with $P$. chabaudi (2 $\times 10^{5} \mathrm{IRBC} /$ mouse) intraperitoneally, and parasitemia was determined in blood smears daily. When the parasitemia reached $1 \%$, the mice were randomly divided into three groups (five mice per group). Each group received $200 \mu \mathrm{l}$ of either $\mathrm{TNF}_{(70-80)}$ or control peptide (at $5 \mathrm{mg} / \mathrm{kg}$ body wt) or saline intraperitoneally daily for 4 consecutive $d$. Blood smears were taken daily for $8 \mathrm{~d}$, and the mice were killed.

Blood smears were stained with Giemsa and examined at a magnification of 1,000 . A minimum of $10,000 \mathrm{RBC}$ were studied per mouse at a time, and the number of parasites found per $100 \mathrm{RBC}$ was expressed as parasitemia.

\section{Effects of peptide TNF $(70-80)$ and TNF in mice}

The standard D-galactosamine-sensitized mouse model was used to evaluate the possible toxic effects of TNF and TNF $(70-80) .20 \mathrm{BALB} / \mathrm{c}$ mice ( 8 wk old) were divided into two groups, and each group was coadministered intraperitoneally $100 \mu \mathrm{l}$ of distilled water containing Dgalactosamine ( $80 \mathrm{mg} / \mathrm{kg}$ body wt) with either TNF $(0.25 \mathrm{mg} / \mathrm{kg} / \mathrm{body}$ $w t)$ or $\operatorname{TNF}_{(70-80)}(500 \mathrm{mg} / \mathrm{kg} /$ body wt). The animals were observed for signs of toxic effects.

\section{Chemiluminescence (CL) assay}

The lucigenin and luminol-dependent $\mathrm{CL}$ assays were conducted as a measurement of the production of oxygen-derived reactive species as described previously (33). Either peptide $\operatorname{TNF}_{(70-80)}(0.01-100 \mu \mathrm{g})$, control peptide $(0.01-100 \mu \mathrm{g})$, or diluent was added to aliquots of PMN ( $10^{6}$ in $100 \mu \mathrm{l}$ HBSS $)$ in $2-\mathrm{ml}$ vials and incubated at $37^{\circ} \mathrm{C}$ for $30 \mathrm{~min}$ in $5 \% \mathrm{CO}_{2}$ in air. In a separate set of experiments, PMN were incubated with $100 \mu \mathrm{l}$ of HBSS containing mAb against TNF or TNF receptors before the addition of TNF, peptides, or diluent. At the end of the 30-min incubation period, $500 \mu \mathrm{l}$ of lucigenin ( $250 \mu \mathrm{M}$, final) or luminol ( $40 \mu \mathrm{g} / \mathrm{ml}$, final) was added, and the final volume was adjusted to $1 \mathrm{ml}$. Where the priming effects for FMLP were studied, $100 \mu \mathrm{l}$ of FMLP or HBSS was added before adjustment of the volume to $1 \mathrm{ml}$. The resulting light output was measured in a water-jacketed $\left(37^{\circ} \mathrm{C}\right)$ luminometer (1251, Bio-Orbit Oy, Turku, Finland) and converted into millivolts using Multiuse software (1.08; Bio-Orbit Oy).

\section{Degranulation}

PMN ( $10^{7}$ in $200 \mu$ l of HBSS) were pretreated with the peptides or diluent as described above, and the supernatants were saved for detection of vitamin $\mathbf{B}_{12}$-binding protein and $\beta$-glucuronidase. The total respective enzyme content of PMN was obtained by incubating the same number of cells with $20 \mu \mathrm{l}$ of $10 \%$ Triton X-100 for $30 \mathrm{~min}$ in $1 \mathrm{ml}$ of HBSS. The results were then expressed as percent release of total enzyme.

Vitamin $\mathbf{B}_{12}$-binding protein release was assayed as described previously (34). Aliquots $(100 \mu \mathrm{l})$ of PMN supernatants were incubated for $15 \mathrm{~min}$ at room temperature with $1 \mathrm{ml}$ of HBSS containing $0.2 \%$ Triton X-100 and cyano- $\left[{ }^{57} \mathrm{Co}\right]$ cobalamine $(100 \mu \mathrm{l}, 0.05 \mu \mathrm{Ci}, 1.9 \mathrm{kBq})$. At the end of the incubation, $2.5 \%(2 \mathrm{ml})$ aqueous charcoal solution was added, and the samples were centrifuged at $3,000 \mathrm{~g}$ for $10 \mathrm{~min}$. Aliquots of the supernatants were counted in a gamma counter (1282 Compugamma; LKB-Wallac).

$\beta$-Glucuronidase activity was determined fluorimetrically with 4methylumbelliferyl- $\beta$-D-glucuronide as substrate as described previously (35), with the following modifications. Aliquots $(50 \mu \mathrm{l})$ of PMN supernatants were incubated for $3 \mathrm{~h}$ at $37^{\circ} \mathrm{C}$ with $50 \mu \mathrm{l}$ of 2.5 $\mathrm{mM}$ substrate in $0.1 \mathrm{M}$ citric acid/sodium phosphate buffer ( $\mathrm{pH} 4.5$ ). The reaction was stopped by the addition of $1.5 \mathrm{ml}$ of $0.2 \mathrm{M}$ glycine/ 


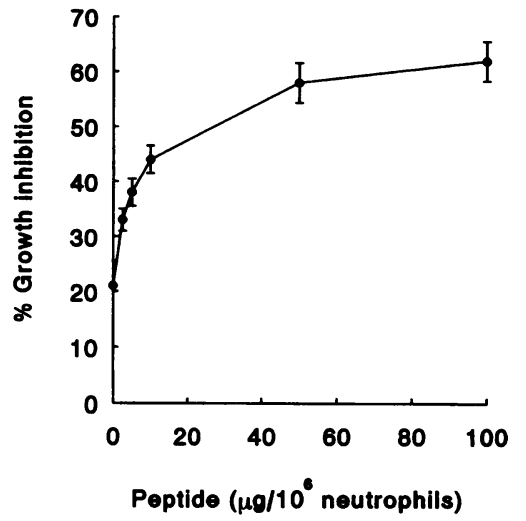

Differences between $\mathrm{TNF}_{(70-80)}$ and the diluent or control peptide throughout the dosage range were significant $(P<0.01)$.

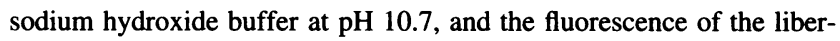
ated 4-methylumbelliferone was quantitated using excitation and emission wavelengths of 366 and $446 \mathrm{~nm}$, respectively. Results are expressed as the percentage of the total $\beta$-glucuronidase or binding protein content released.

\section{Expression of PMN integrin and Fc receptors}

FACS $^{\circledR}$ analyses of integrins and Fc receptors were conducted as described previously $(7)$. PMN $\left(2 \times 10^{5}\right)$ were pretreated with either $\mathrm{TNF}_{(70-80)}(100 \mu \mathrm{g})$ or HBSS for $20 \mathrm{~min}$ at $37^{\circ} \mathrm{C}$ in tubes $(3 \mathrm{ml})$, washed once with ice-cold PBS, and incubated for $30 \mathrm{~min}$ at $4^{\circ} \mathrm{C}$ with saturating concentrations of mAb against (a) FcR $\gamma \mathrm{II}$ and FcR $\gamma \mathrm{III},(b)$ integrin family of adhesive glycoproteins (CD11/CD18 complex); MHM-23 (common chain defined as CD-18 antigen) and mAb reacts with three different chains; MHM-23 (CD11a), WM20 (CD11b), KB90 (CD11c); (c) isotype-matched negative controls Sal 4 (IgG2b), Sal 5 $(\operatorname{IgG} 2 \mathrm{a})$, and X63 $(\mathrm{IgG1}-\kappa)$; and $(d)$ an unrelated mAb FMC 16 (IgG2a). The cells were washed with ice-cold PBS and then stained with fluorescein-conjugated second $\mathrm{mAb}$ (goat anti-mouse IgG, Organon Teknika, Rockville, MD) in the presence of autologous plasma. PMN were washed twice with cold PBS and fixed with paraformaldehyde ( $1 \% \mathrm{wt} / \mathrm{vol})$. The distribution of fluorescence was measured using a FACS ${ }^{\circledR}$ analyzer. The values were corrected by subtraction of those for isotype-matched negative controls.

Determination of the expression of ELAM-1, ICAM-1, and VCAM-1 molecules on HUVEC

Endothelial cells were maintained in gelatin-coated 96-well microdilution plates. When the cells were confluent, the medium was removed, washed with HBSS-A, and then incubated with $100 \mu \mathrm{l}$ of TNF (100 $\mathrm{U}), \mathrm{TNF}_{(70-80)}(100 \mu \mathrm{g})$, and diluent, for $4 \mathrm{~h}$ (for ICAM-1 and ELAM1) and $18-24 \mathrm{~h}$ (for VCAM-1), at $37^{\circ} \mathrm{C}$ in $5 \% \mathrm{CO}_{2}$. The media from the wells were removed and washed three times with HBSS-A. $100 \mu \mathrm{l}$ of $0.025 \%$ glutaraldehyde in PBS was added and incubated overnight at $4^{\circ} \mathrm{C}$. The wells were washed three times and the primary mAb (mouse anti-human) against ICAM-1 (at 1/2,500), ELAM-1 (at 1/1,500), or VCAM-1 (at 1/1,000) was added. After incubation for $1 \mathrm{~h}$ at room temperature, the wells were washed three times with HBSS, and 100 $\mu \mathrm{l}$ of the horseradish peroxidase-conjugated rabbit immunoglobulins to mouse immunoglobulins at $1 / 1,000$ were added. The wells were washed three times, and the ABTS substrate $(100 \mu \mathrm{l})$ was added and incubated until the color developed sufficiently to read. The absorbance $(410 \mathrm{~nm})$ was determined using a plate reader (MR7000; Dynatech Laboratories, Inc., Chantilly, VA).

\section{Testing for possible bacterial LPS contamination}

Working and stock solutions of TNF, peptides, media, PBS, and HBSS were routinely tested for LPS by limulus amebocyte lysate assay. TNF

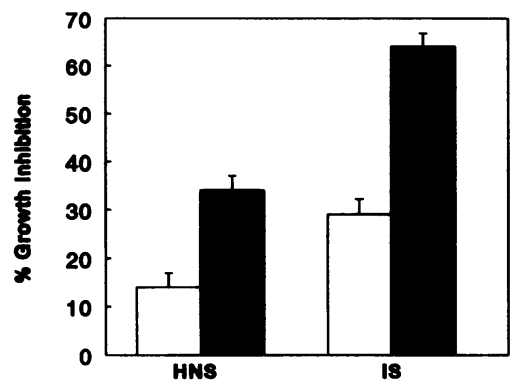

Figure 3. Effects of $\operatorname{TNF}_{(70-80)}(\square)$ and diluent ( $\square$ ) on the inhibition of $\left[{ }^{3} \mathrm{H}\right]$ hypoxanthine uptake by $P$. falciparum after interaction with PMN in the presence of heated NS and malaria IS. Results are presented as the mean \pm SEM of nine experiments, each conducted with PMN

from a different donor. The results of the control peptide were similar to the diluent effect and significantly lower $(P<0.001)$ than the TNF $_{(70-80)}$-treated PMN effects.

and peptide preparations were heated at $80^{\circ} \mathrm{C}$ for $30 \mathrm{~min}$ (which inactivates TNF and peptides but leaves the LPS activity intact) and compared with the nonheated cytokines. Experiments were also conducted in the presence of polymyxin-B $(\mathrm{I} \mu \mathrm{g} / \mathrm{ml})$. The peptides and TNF were filtered through a positively charged filter (Zetapor filters; Cuno, Inc., Meriden, CT), and the filtrates were used in experiments. In addition, a TNFneutralizing $\mathrm{mAb}$ was used to ensure that the activity was due to the cytokine.

\section{Statistical analysis}

The results were compared by the two-tailed Student's $t$ test.

\section{Results}

TNF ${ }_{(70-80)}-$ induced PMN priming for increased parasite killing

We have previously demonstrated that the PMN-activating properties of TNF were reflected in its ability to prime the phagocyte for increased killing of $P$. falciparum asexual blood stages $(17,18)$. Therefore, the peptide $\operatorname{TNF}_{(70-80)}$ (Fig. 1) was examined for PMN priming in relation to this activity. PMN were pretreated with a range of concentrations of the peptide $\left(2-100 \mu \mathrm{g} / 10^{6}\right.$ cells) and then mixed with $P$. falciparum and NS. The $\mathrm{TNF}_{(70-80)}$ peptide significantly enhanced the PMNmediated killing of $P$. falciparum over this dose range (Fig. 2). Under the same conditions and identical dose range, the control peptide failed to enhance the antimalarial activity of PMN (Fig. 2 ). The peptides had no direct effect on parasites.

The priming effects of $\mathrm{TNF}_{(70-80)}$ were evident also in the presence of immune serum containing anti- $P$. falciparum antibodies (Fig. 3 ). In the presence of heated normal serum, $\mathrm{TNF}_{(70-80)}$ caused a doubling in parasite killing $(P<0.025)$. There was a further doubling in killing $(P<0.001)$ if immune serum was added. There was no difference in relation to the $\mathrm{TNF}_{(70-80)}$-enhanced neutrophil-mediated killing of knob-less or knob-positive isolates of $\boldsymbol{P}$. falciparum.

Microscopical studies showed that either $\mathrm{TNF}_{(70-80)}$ or the control peptide had no effect on parasite morphology or viability. The neutrophils killed $P$. falciparum by binding to IRBC and phagocytosing the parasites. TNF $_{(70-80)}$ or the control peptide did not cause any observable morphological abnormality to PMN.

\section{Effect of $T N F_{(70-80)}$ on $P$. chabaudi infection}

To see if the immuno-enhancing properties of $\mathrm{TNF}_{(70-80)}$ were reflected in an increase in resistance against malaria, the effects of the peptide on the course of a murine malaria species were examined. In the first set of experiments, the mice infected with 
Table I. Treatment of $P$. chabaudi-infected Mice with $T N F_{(70-80)}$ Peptide

\begin{tabular}{lrrr}
\hline \multirow{2}{*}{$\begin{array}{c}\text { Days after } \\
\text { infection }\end{array}$} & \multicolumn{2}{c}{ Parasitemia (mean \pm SD) } & \\
\cline { 2 - 3 } & $\mathrm{TNF}_{(70-80)}$ & \multicolumn{1}{c}{ Control peptide } & \\
\hline & & & $P$ \\
1 & $0.03 \pm 0.05$ & Undetectable & \\
3 & $0.50 \pm 0.20$ & $0.37 \pm 0.15$ & \\
$4^{*}$ & $1.53 \pm 0.25$ & $3.50 \pm 1.00$ & $<0.01$ \\
5 & $2.30 \pm 0.05$ & $5.97 \pm 1.60$ & $<0.01$ \\
6 & $8.20 \pm 2.30$ & $24.00 \pm 5.00$ & $<0.002$ \\
7 & $20.70 \pm 4.00$ & $37.20 \pm 5.50$ & $<0.01$ \\
8 & $63.50 \pm 0.05$ & $178.00 \pm 37.6$ & $<0.01$ \\
\hline
\end{tabular}

Mice were treated with $\mathrm{TNF}_{(70-80)}$ and control peptide $(5 \mathrm{mg} / \mathrm{body} \mathrm{wt} /$ d) starting from day 4.* The parasitemia was measured $7 \mathrm{~h}$ after the first treatment. Two control groups received either control peptide or saline (data not presented). There was no significant difference between the control peptide-treated groups and saline-treated group. The results shown are from the representative experiment (five mice per group) of three total experiments.

$P$. chabaudi $\left(2 \times 10^{5} \mathrm{IRBC}\right)$ were divided into three groups, and the parasitemia was measured daily. On the fourth day mice in one group were treated with $0.5 \mathrm{mg} / \mathrm{kg}$ body wt of $\mathrm{TNF}_{(70-80)}$, while the second group received an equivalent amount of the control peptide, and the third received normal saline. The animals continued to be treated once daily for $4 \mathrm{~d}$. Within $7 \mathrm{~h}$ after TNF $_{(70-80)}$ treatment, the fold increase in average parasitemia was reduced from $\sim 10$ (control peptide) to 3 for $\mathrm{TNF}_{(70-80)}$ (Table I). By day eight the fold increase of parasites from day three was $\mathbf{4 8 0}$ for the control peptide compared to 127 for the $\mathrm{TNF}_{(70-80)}$-treated mice (Table I). There was no difference between parasitemias of mice that received control peptide or normal saline (data not presented). Mice that were treated with the peptides did not show any toxic changes such as diarrhea or any neurological symptoms.

\section{Effect of $T N F_{(70-80)}$ in D-galactosamine-sensitized mice}

D-galactosamine-sensitized normal BALB/c mice were treated with either TNF $(0.25 \mathrm{mg} / \mathrm{kg}$ body wt $)$ or $\mathrm{TNF}_{(70-80)}(500 \mathrm{mg} /$ $\mathrm{kg}$ body wt). All mice that received TNF showed ruffled fur, hunched posture, touch sensitivity, blepharitis, hypothermia, and hemiplegia, and $70 \%$ died within $48 \mathrm{~h}$. By contrast, none of the mice that received the peptide showed any sign of toxicity during this period or subsequently.

\section{Mechanisms of $T N F_{(70-80)}$-induced priming}

Previously it has been demonstrated that the TNF-induced priming of increased antimicrobial activity of PMN is associated with an increased expression of integrin and $\mathrm{Fc} \gamma$ receptors, increased generation of oxygen-derived reactive species, and increased degranulation response (for review, see reference 6). We therefore proceeded to characterize the $\mathrm{TNF}_{(70-80)}$ properties in relation to the above activities.

Priming for increased respiratory burst and degranulation. To simplify the assessment of $\mathrm{TNF}_{(70-80)}$-induced priming, we examined the priming effect for the agonist FMLP. Lucigenindependent chemiluminescence assay was used as a measure of superoxide production by PMN. The peptide significantly

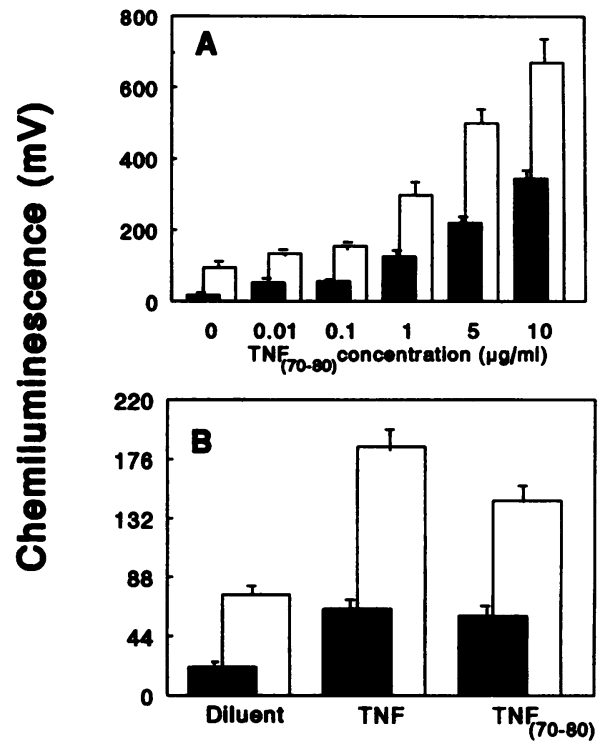

Figure 4. The effects of $\mathrm{TNF}_{(70-80)}$ on lucigenin-dependent $\mathrm{CL}$ response of PMN. Activation of CL by $\operatorname{TNF}_{(70-80)}(\varpi)$ and the priming for a second stimulant, FMLP (ם). (A) Dose-dependent (0.01-10 $\mu \mathrm{g})$ effects of $\operatorname{TNF}_{(70-80)}$ on PMN $\left(10^{6}\right)$. The response induced by the control peptide-treated PMN was similar to the diluent effect (as shown as 0 concentration). The results are presented as mean \pm SEM of triplicate of a representative experiment of three carried out using PMN from different individuals $(P<0.001)$. (B) Comparative effects of TNF $(100 \mathrm{U}), \operatorname{TNF}_{(70-80)}(0.01 \mu \mathrm{g})$, and diluent. The results represent mean \pm SEM of three experiments conducted in triplicate, with PMN from different donors. The effects of the control peptide were the same as for diluent and were significantly $(P<0.001)$ lower than the responses given by either TNF- or $\mathrm{TNF}_{(70-80)}-$ treated PMN.

stimulated $(P<0.001) \mathrm{PMN}$ and also primed $(P<0.001)$ for the chemiluminescence response to FMLP (Figs. 4 and 5). Enhancement was evident at $0.01-10 \mu \mathrm{g} / \mathrm{ml}$ of $\mathrm{TNF}_{(70-80)}$ (Fig.

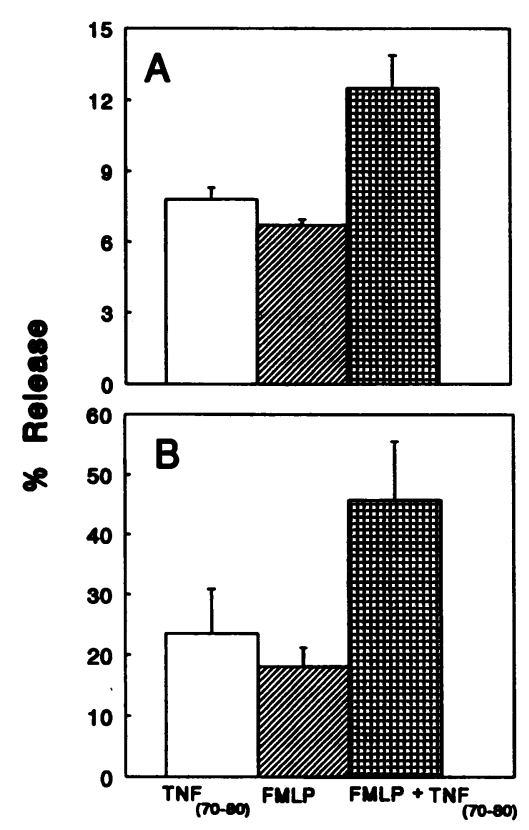

Figure 5. The effects of $\mathrm{TNF}_{(70-80)}$ on PMN release of $(A) \beta$-glucuronidase, and $(B)$ vitamin $B_{12}$-binding protein, in either the presence or absence of FMLP. Results represent mean \pm SEM of nine experiments, each conducted in triplicate with PMN ( $10^{6} /$ tube) from different individuals. The basal PMN release responses have been deducted from the those of the agonistinduced effects. $(A)$ Comparisons between TNF $_{(70-80)}+$ FMLP and diluent + FMLP $(P<0.01)$. (B) Comparisons between $\mathrm{TNF}_{(70-80)}$ and diluent $(P<0.001)$, FMLP $+\mathrm{TNF}_{(70-80)}$, and FMLP + diluent $(P<0.001)$. 

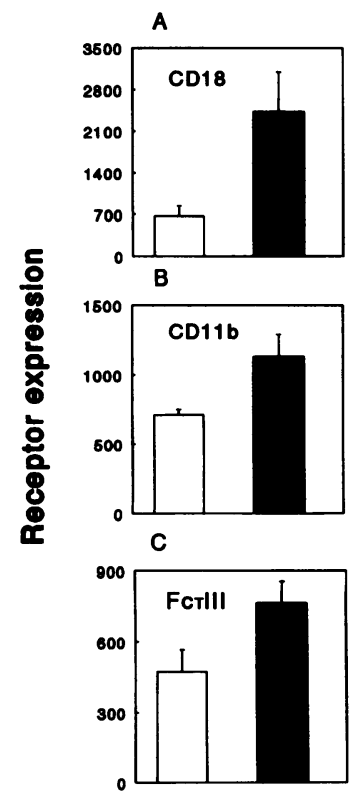

Figure 6. The effects of either $\operatorname{TNF}_{(70-80)}$ $(\square)$ or diluent ( $\square$ ) on PMN integrin and Fc $\gamma$ III receptor expression. PMN were preincubated with either peptide or diluent for $20 \mathrm{~min}$. (A) A representative experiment of four, when treated with mAb for CD18 (MHM-23). (B) A representative experiment of four, using mAb to CD11b (FMC 16). (C) A representative experiment of three, using $\mathrm{mAb}$ to Fc $\gamma$ RIII. Mean \pm SD of triplicates are given. Comparison between diluent- and $\mathrm{TNF}_{(70-80)}$-treated PMN in all experiments gave $P<0.01(A), P$ $<0.01(B)$, and $P<0.05(C)$.

4). A similar trend was also seen for luminol-dependent PMN chemiluminescence response (data not presented). Fig. 5 shows a comparison between TNF (100 U) and $\operatorname{TNF}_{(70-80)}(0.01 \mu \mathrm{g} /$ $\mathrm{ml})$. Both significantly stimulated $(P<0.001)$ PMN for lucigenin-enhanced chemiluminescence response and also primed $(P<0.001)$ the cells to FMLP.

Degranulation was measured as the release of $\beta$-glucuronidase and vitamin B-12-binding protein, which are markers of specific and azurophilic granules, respectively. While $\mathrm{TNF}_{(70-80)}$ induced only a small and nonsignificant release of $\beta$-glucuronidase (Fig. $5 A$ ), it still primed for an increased release $(P<0.01)$ of this enzyme, in response to FMLP (Fig. $5 A) . \mathrm{TNF}_{(70-80)}$ induced a direct degranulation response, increasing the basal vitamin $B_{12}$-binding protein (14.5 \pm 1.5$)$ by 2.8-fold $(P<0.001)$, with a further 3.1 -fold increase with FMLP (Fig. $5 B)(P<0.001)$.

Modulation of surface expression of integrin and Fc receptor expression. This was assessed by flow cytometry using $\mathrm{mAb}$. Pretreatment of PMN with $\mathrm{TNF}_{(70-80)}$ significantly $(P<0.01)$ increased the expression of $\mathrm{CD} 18$, the common $\beta$-chain of the integrin receptors (Fig. $6 \mathrm{~A}$ ). When the expression of the $\alpha$ chains (CD11a, CD11b, and CD11c) was examined, $\mathrm{TNF}_{(70-80)}$ induced a significant $(P<0.05)$ increase in expression of CD11b (Fig. $6 \mathrm{~B}$ ) but not CD11a or CD11c (data not presented).

Treatment of PMN with $\mathrm{TNF}_{(70-80)}$ caused a significant $(P$ $<0.05$ ) increase in the FcR $\gamma$ III expression (Fig. $6 C$ ) but no significant increase in expression of $\mathrm{FcR} \gamma \mathrm{II}$ (data not presented).

Interaction of $T N F_{(70-80)}$ with $T N F$ receptors. The effects of $\mathrm{TNF}_{(70-80)}$ are most likely mediated via the TNF receptors. We attempted to investigate this possibility by making a modified $\mathrm{TNF}_{(70-80)}$ containing a tyrosine that could be iodinated as the carboxy-terminal amino acid for receptor binding studies. However, the modified peptide did not stimulate the PMN respiratory burst and failed to associate with PMN in binding assays. Therefore, an alternative approach was used to determine whether or not $\mathrm{TNF}_{(70-80)}$ binds to the TNF receptor.

Anti-TNF monoclonal antibody (mAb54) that neutralized

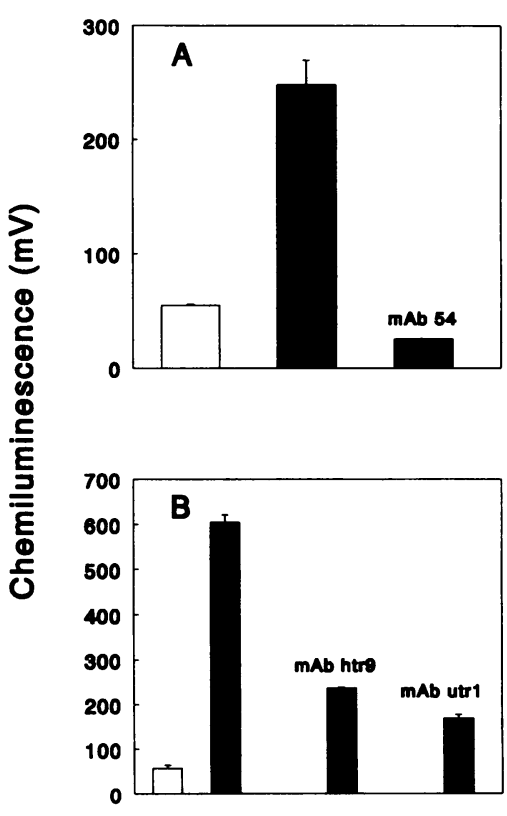

Figure 7. The effect of anti-TNF neutralizing antibody on $\mathrm{TNF}_{(70-80)}-$ $(\square)$ or diluent treated $(\square)$ (30 min) PMN on the lucigenin-enhanced chemiluminescence response. $(A)$ Effects of anti-TNF mAb (mAb 54). (B) Effects of mAb against TNF receptors, TNFR 55 (htr 9), and TNFR 75 (utr 1) on TNF $_{(70-80)}$-induced PMN response. The results are presented as mean \pm SD of triplicate of a representative experiment of three sets carried out using PMN from different individuals. AntiTNF mAb or htr 9 and utr 1 did not inhibit the $\mathrm{CL}$ response of the control peptide.

the activity of TNF was examined for ability to inhibit the peptide-induced respiratory response. The peptide-induced lucigenin-dependent chemiluminescence response was inhibited by mAb54 (Fig. $7 A$ ). In a second set of experiments, the peptide was treated with mAb against either the p75 (utr 1) or p55 (htr 9) TNF receptors (at $10 \mu \mathrm{g} / \mathrm{ml}$ ). The results showed that both antibodies inhibited the ability of $\mathrm{TNF}_{(70-80)}$ peptide to stimulate lucigenin-dependent CL response in PMN (Fig. 7 B).

\section{Effect of $T N F_{(70-80)}$ on endothelial cell adhesion function}

A major pathophysiology-inducing characteristic of TNF is its ability to increase the adhesive properties of the endothelium. We therefore compared the ability of TNF and TNF $(70-80)$ peptide to alter the expression of adhesion molecules on endothelial cells and their ability to increase adhesion of IRBC to the endothelial cells.

Expression of ELAM-1, ICAM-1, and VCAM-1. The expression of three adhesion molecules on endothelial cells was studied after pretreatment with either TNF, $\mathrm{TNF}_{(70-80)}$, or diluent. The data presented in Fig. 9 show that expression of all three adhesion molecules is increased by TNF $(P<0.001)$. In contrast, $\mathrm{TNF}_{(70-80)}$ did not increase their expression (Fig. 8), even when the concentration was increased to $1 \mathrm{mM}$ (data not shown).

Sequestration of IRBC. Since the pathological consequence of TNF interaction with endothelial cells in cerebral malaria is to increase the adhesion of IRBC, we tested whether the TNF $_{(70-80)}$ peptide had similar activity. The endothelial cells were pretreated with these agents, and then adhesion of IRBC to the endothelial cells was assessed by either microscopic examination (Fig. $9 A$ ) or a radiometric assay (Fig. $9 B$ ). The results showed that TNF significantly enhanced $(P<0.05)$ the adherence of IRBC to HUVEC (Fig. 9). In contrast, when endothelial cells were pretreated with $\mathrm{TNF}_{(70-80)}$, no increase of IRBC adherence was evident (Fig. 9). Morphological observations confirmed that the addition of the peptides or TNF to 


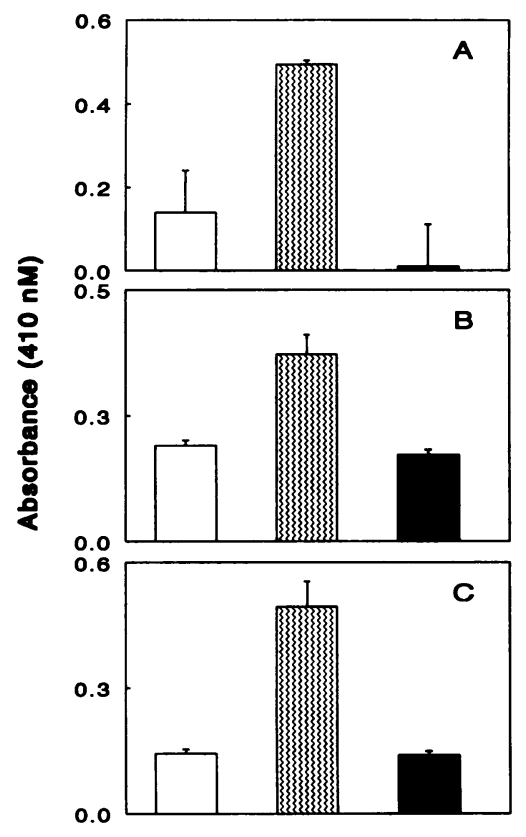

Figure 8 . The effects of $\mathrm{TNF}_{(70-80)}$ peptide ( $\left.\square\right)$, TNF ( (s), and diluent

() on the induction of ( $A$ ) ELAM-1, $(B)$ ICAM-1, and $(C)$ VCAM-1 on HUVEC. Results are presented as mean \pm SD of triplicates and are representative of three experiments. Significantly lower expressions of all the three adhesion molecules were seen when the cells were treated with either the diluent or $\mathrm{TNF}_{(70-80)}$ rather than the TNF treatment in three experiments $(P<0.001)$.

HUVEC did not affect the viability of endothelial cells or the parasite (data not shown).

\section{Effect of $T N F_{(70-80)}$ peptide on TNF enhancement of IRBC} adherence to endothelial cells

Since the TNF $_{(70-80)}$ peptide interacts with TNF receptors, it should be possible to inhibit the effects of TNF on endothelial cells. We examined whether pretreatment of HUVEC with the TNF $_{(70-80)}$ peptide could prevent the ability of TNF to enhance adhesion of IRBC to HUVEC. The results showed that when the cells were pretreated with TNF in the presence of

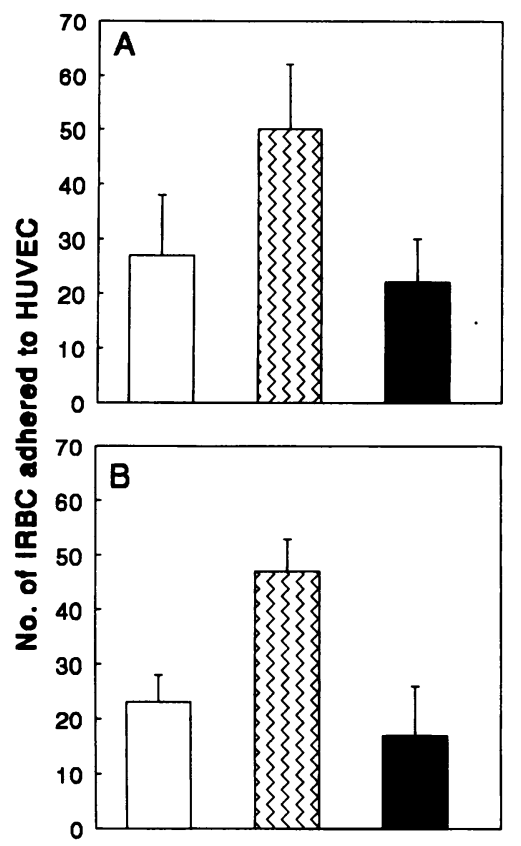

Figure 9. The effects of $\mathrm{TNF}_{(70-80)}(\boldsymbol{\square})$, diluent (), and TNF ( ( $)$ treatment on the HUVEC binding of IRBC. $(A)$ Morphological quantification: Mean \pm SEM of six experiments (HUVEC from six sources, in duplicates) are shown.

(B) Radiometric quantification: Parasites were labeled with $\left[{ }^{3} \mathrm{H}\right]$ hypoxanthine and incubated with HUVEC, and the adherence of IRBC was calculated. Mean \pm SEM of three experiments (HUVEC from three sources, each conducted in six wells) are shown. Comparison between diluent- or $\left.\mathrm{TNF}_{(70-80)}\right)^{-}$ treated HUVEC against TNF-treated cells gave $P$ $<0.05(A)$ and $P<0.05(B)$. There was no significant difference between the control peptide-and diluent-treated HUVEC.

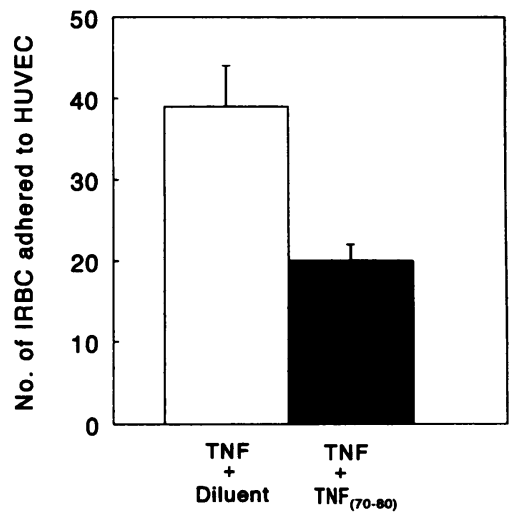

Figure 10. The effects of $\mathrm{TNF}_{(70-80)}$ on the TNFinduced enhanced adherence of IRBC to HUVEC. Using a radiometric assay, the binding of IRBC was assessed after pretreatment of HUVEC with mixtures of diluent + TNF ( $\square)$ or TNF $_{(70-80)}$ + TNF ( $\square)$. Parasites were prelabeled with $\left[{ }^{3} \mathrm{H}\right]$ hypoxanthine and incubated with HUVEC, and the adherence of IRBC was determined.

Mean \pm SEM of 12 determinations using HUVEC from 3 cords are given. The adherence of IRBC treated with the diluent alone was 24 \pm 3.1 . Comparison between TNF-treated cells and TNF $+\mathrm{TNF}_{(70-80)}$-treated cells gave $P<0.05$.

$\mathrm{TNF}_{(70-80)}$ peptide, the cells failed to show increased IRBC binding (Fig. 10).

\section{Testing for LPS contamination}

The possibility that endotoxin contamination is responsible for the effects of TNF and TNF $(70-80)$ was tested. In two experiments where $P$. falciparum killing ability was compared using neutrophils pretreated with $\mathrm{TNF}_{(70-80)}$, TNF, and the diluent, percent growth inhibition of the parasite (in the presence of NS) was $53 \pm 2.8,47.5 \pm 3.2$, and $25.2 \pm 1.9$, respectively. These values were $56 \pm 3.2,45.5 \pm 3.7$, and $28.2 \pm 2.5$ after incubation of the peptide, TNF, and HBSS with polymyxin-B $(1 \mathrm{mg} / \mathrm{ml})$, for 15 min at room temperature and then used to treat the neutrophils. Within the same experiments, $\mathrm{TNF}, \mathrm{TNF}_{(70-80)}$, and diluent were heated at $80^{\circ} \mathrm{C}$ for $30 \mathrm{~min}$ before the treatment with neutrophils. Heating completely abolished the activity of TNF and $\mathrm{TNF}_{(70-80)}$, giving a percent growth inhibition of $23.8 \pm 2.5$ and $28.5 \pm 2.5$, respectively. The peptide and TNF were filtered through a positively charged filter (Zetapore) to remove LPS, and the filtrates were incubated with neutrophils. Using $\mathrm{CL}$ technique (as described above), neutrophil-stimulatory activity of the filtrates was tested in the presence of lucigenin. The results from two experiments showed that the CL responses of the filtered $\mathrm{TNF}_{(70-80)}$ and TNF were similar to those of nonfiltered cytokine and the peptide (data not presented). Furthermore, mAb against TNF neutralized the neutrophil-stimulatory activity of the peptide as well as TNF (results shown above).

\section{Discussion}

A synthetic peptide that covers the region between 70 and 80 in the TNF amino acid sequence has been shown to prime PMN for increased antimicrobial activity. Pretreatment of PMN with the peptide $\mathrm{TNF}_{(70-80)}$ significantly enhanced their ability to kill the intraerythrocytic asexual blood stage of $P$. falciparum. This property of the peptide was reflected in its ability to show antimalaria activity in vivo. Intraperitoneal administration of TNF $_{(70-80)}$ once daily for $4 \mathrm{~d}$ resulted in a significant reduction in parasitemia in $P$. chabaudi-infected mice.

While $\mathrm{TNF}_{(70-80)}$ increased the PMN-mediated killing of $P$. falciparum in the absence of opsonins, the greatest effects were 
seen in the presence of either complement or antimalaria antibodies. This was consistent with the finding that the peptide increased the expression of CR3 and FcR $\gamma$ III on PMN, providing the first step in the mechanism of $\mathrm{TNF}_{(70-80)}$-mediated PMN priming. This would lead to increased interaction of parasites with PMN, most likely enhancing phagocytosis and parasite destruction. The increased receptor expression was closely associated with the ability of the peptide to prime PMN for enhanced release of oxygen-derived reactive species and release of constituents from both primary and secondary granules. Clearly, $\mathrm{TNF}_{(70-80)}$ closely resembles the previously described PMN priming properties of TNF $(10-13,36-38)$. It has been shown that $P$. falciparum can be killed by oxygen-derived reactive species as well as with neutrophil granule constituents (6).

Our attempts to delineate the mechanisms of $\mathrm{TNF}_{(70-80)}-$ induced priming demonstrated that its action was mediated via the TNF receptors. A TNF-neutralizing mAb totally inhibited the activity of the peptide. Furthermore, addition of either the anti-p55 or anti-p75 mAbs resulted in significant reduction in the ability of the peptide to activate neutrophils. These findings also suggest that binding to both receptors is required to achieve full PMN-activating properties of the peptide.

The finding that $\mathrm{mAb}$ against TNF neutralized the neutrophil-stimulatory activity of the $\operatorname{TNF}_{(70-80)}$ as well as TNF also suggests that their neutrophil-stimulatory properties were not due to LPS contamination. Confirming this finding, we have also shown that the activity of TNF and $\mathrm{TNF}_{(70-80)}$ was heat labile and was not neutralized by polymyxin-B. After filtration of TNF and $\mathrm{TNF}_{(70-80)}$ through a positively charged membrane (to remove LPS), no change in their activity was observed.

In cerebral malaria, TNF is implicated in the pathology associated with the sequestration of IRBC in the microvasculature of vital organs such as the brain and lungs (22). The results of the present study reemphasize the findings by showing that TNF promotes enhancement of IRBC adherence to cultured endothelial cells. One of the differences observed between TNF $_{(70-80)}$ and TNF was the failure of the peptide to promote adhesion of IRBC to HUVEC. This is consistent with our findings that $\mathrm{TNF}_{(70-80)}$ did not increase the expression of ICAM1, ELAM-1, and VCAM-1 on HUVEC. These molecules are thought to be involved in the adherence of IRBC to endothelial cells $(39,40)$. Our results showed that, unlike TNF, peptide $\mathrm{TNF}_{(70-80)}$ did not promote parasite sequestration, and in fact inhibited the effects of TNF on endothelial cells that lead to enhanced IRBC adhesion. When the endothelial cells were exposed to both TNF and the peptide simultaneously, the peptide inhibited the ability of TNF to enhance IRBC adhesion, presumably because the peptide is competing for the TNF receptors. Since much of the pathology due to $P$. falciparum infection occurs as a consequence of IRBC sequestration to host endothelium, the peptide can be considered to be devoid of this component of the pathophysiology.

The reason for the difference between $\mathrm{TNF}_{(70-80)}$ and TNF on their activities on endothelial cells and their similarities on activation of PMN is not fully understood. It is possible that disparate signal transduction mechanisms are involved for the TNF-induced effects on PMN and endothelial cells where the involvement of $\mathrm{TNF}_{(70-80)}$ differs from the parent cytokine. We are presently investigating the basis of the selective action of $\mathrm{TNF}_{(70-80)}$, including its effects on signal transduction pathways. It is also possible that certain functions of TNF require the trimer form of TNF (e.g., expression of ELAM, ICAM, and
VCAM on endothelial cells and direct tumor toxicity), while for other activities (e.g., activation and priming of PMN) trimer formation may not be essential. Attempts to explain these biological differences could hence be evaluated by engineering a trimer of the peptide with spacers between the active sequences and determining whether the normal TNF activity is regained.

The results of the in vivo toxicity studies showed that the TNF $_{(70-80)}$ peptide does not possess the typical toxic effects of TNF. In D-galactosamine-sensitized mice, while TNF $(0.25$ $\mathrm{mg} / \mathrm{kg}$ body $\mathrm{wt}$ ) caused marked toxic effects and death within $48 \mathrm{~h}, \mathrm{TNF}_{(70-80)}(500 \mathrm{mg} / \mathrm{kg}$ body wt $)$ did not cause toxic changes or death. Results generated in our laboratory have further demonstrated the specific biological properties of $\mathrm{TNF}_{(70-80)}$. The peptide did not induce TNF-like cytotoxicity of WEHI-164 cells in the presence of actinomycin-D and failed to promote neutrophil adherence properties in vitro (unpublished observations; Rathjen, D. A., L. M. Kumaratilake, and A. Ferrante).

The findings reported in this study are of considerable importance in demonstrating that the host-protective effects of a cytokine can be retained while potentially deleterious side effects are eliminated by using a selected, characterized subunit of the cytokine.

\section{Acknowledgments}

We wish to thank Timothy Jaeger, Chris Stewart (Department of Immunology, Women's and Children's Hospital, Adelaide, South Australia), Frances Lemckert, and Louise Furphy (Peptide Technology, Ltd., New South Wales, Australia) for excellent technical assistance. Our thanks also extend to Dr. Christine Rzepczyk (Queensland Institute for Medical Research, Herston, Brisbane, Australia) for providing malaria immune sera from Papua New Guinea. We are grateful to the South Australian branch of the Red Cross Blood Transfusion Centre for providing blood and plasma packs for parasite cultures.

This work was supported by the United Nations Development Program/World Bank/World Health Organization Special Programme for Research and Training in Tropical Diseases and the National Health and Medical Research Council of Australia.

\section{References}

1. Balkwill, F. 1993. Tumour necrosis factor. Improving on the formula. Nature (Lond.). 361:206-207.

2. Beutler, B., and A. Cerami. 1988. The common mediator of shock, cachexia, and tumor necrosis. Adv. Immunol. 42:213-231.

3. Denis, M., and K. Chadee. 1989. Human neutrophils activated by interferon$\gamma$ and tumour necrosis factor- $\alpha$ kill Entamboeba histolytica trophozoites in vitro. J. Leukocyte Biol. 46:270-274.

4. Ferrante, A. 1989. Tumor necrosis factor alpha potentiates neutrophil antimicrobial activity: increased fungicidal activity against Torulopsis glabrata and Candida albicans and associated increase in oxygen radical production and lysosomal enzyme release. Infect. Immun. 57:2115-2122.

5. Jupin, C., M. Parant, and L. Chedid. 1989. Involvement of reactive oxygen metabolites in the Candidacidal activity of human neutrophils stimulated by muramyl dipeptide or tumor necrosis factor. Immunobiology. 180:68-79.

6. Ferrante, A., L. M. Kumaratilake, and D. A. Rathjen. 1993. The role of cytokine-activated phagocytic cells in immunity to malaria. In Molecular Immunological Considerations in Malaria Vaccine Development. M. F. Good and A. J. Saul, editors. CRC Press, Inc., Boca Raton. 47-97.

7. Ferrante, A., A. J. Martin, E. J. Bates, D. H. B. Goh, D. P. Harvey, D. Parsons, D. A. Rathjen, G. Russ, and J.-M. Dayer. 1993. Killing of Staphylococcus aureus by tumor necrosis factor- $\alpha$ activated PMN: the role of serum opsonins, integrin receptors, respiratory burst and degranulation. J. Immunol. 151:48214828.

8. Playfair, J. H. L., and J. Taverne. 1987. Antiparasitic effects of tumour necrosis factor in vivo and in vitro. CIBA Found. Symp. 131:192-205.

9. Rothe, J., W. Lesslauer, H. Lotscher, Y. Lang, P. Koebel, F. Kontgen, A Althage, R. Zinkernael, M. Steinmetz, and H. Bluethmann. 1993. Mice lacking 
the tumour necrosis factor receptor 1 are resistant to TNF- $\alpha$ mediated toxicity but highly susceptible to infection by Listeria monocytogenes. Nature (Lond.). 364:798-802.

10. Figari, I. S., N. A. Mori, and M. A. Palladino, Jr. 1987. Regulation of neutrophil migration and superoxide production by recombinant tumor necrosis factors- $\alpha$ and $-\beta$ : comparison to recombinant interferon and interleukin-1. Blood. 70:979-984.

11. Klebanoff, S. J., M. A. Vadas, J. M. Harlan, L. H. Sparks, J. R. Gamble, J. M. Agosti, and A. M. Walterdorph. 1986. Stimulation of neutrophils by tumor necrosis factor. J. Immunol. 136:4220-4225.

12. Nathan, C. F. 1987. Neutrophil activation on biological surfaces: massive secretion of hydrogen peroxide in response to products of macrophages and lymphocytes. J. Clin. Invest. 80:1550-1560.

13. Ferrante, A., M. Nandoskar, A. Walz, D. H. B. Goh, and I. C. Kowanko. 1988. Effects of tumor necrosis factor alpha and interleukin-1 alpha and beta on human neutrophil migration, respiratory burst and degranulation. Int. Arch. Allergy Appl. Immunol. 86:82-91.

14. Melancon-Kaplan, J., and W. P. Weidanz. 1989. Role of cell-mediated immunity in resistance to malaria. In Malaria: Host Responses to Infection. M. M Stevenson, editor. CRC Press, Inc., Boca Raton. 48-50.

15. Nnanlue, N. A., and M. J. Friedman. 1988. Evidence for a neutrophil mediated protective response in malaria. Parasite Immunol. (Oxf.). 10:47-53.

16. Kharazmi, A., and S. Jepsen. 1984. Enhanced inhibition of in vitro multiplication of Plasmodium falciparum by stimulated human polymorphonuclear leukocytes. Clin. Exp. Immunol. 57:287-292.

17. Kumaratilake, L. M., A. Ferrante, and C. M. Rzepczyk. 1990. Tumor necrosis factor enhances neutrophil-mediated killing of Plasmodium falciparum. Infect. Immun. 58:788-793.

18. Kumaratilake, L. M., A. Ferrante, and C. M. Rzepczyk. 1991. The role of T lymphocytes in immunity to Plasmodium falciparum. Enhancement of neutrophil-mediated parasite killing by lymphotoxin and IFN: comparisons with tumor necrosis factor effects. J. Immunol. 146:762-767.

19. Kumaratilake, L. M., A. Ferrante, T. Jaeger, and C. M. Rzepczyk. 1992. Effects of cytokines, complement, and antibody on the neutrophil respiratory burst and phagocytic response to Plasmodium falciparum merozoites. Infect. Immun. 60:3731-3738.

20. Beutler, B., I. W. Milsark, and A. C. Cerami. 1985. Passive immunization against cachectin/tumor necrosis factor protects mice from lethal effect of LPS. Science (Wash. DC). 229:869-871.

21. Keffer, J., L. Probert, H. Cazizris, S. Georgopoulos, E. Kaslaris, D. Kioussis, and G. Kollias. 1991. Transgenic mice expressing human tumor necrosis factor: a predictive genetic model of arthritis. EMBO (Eur. Mol. Biol. Organ.) J. 10:4025-4031

22. Grau, G. E., P.-F. Piguet, P. Vassalli, and P.-H. Lambert. 1989. Tumornecrosis factor and other cytokines in cerebral malaria: experimental and clinical data. Immunol. Rev. 112:49-70.

23. Warrell, D. A. 1987. Pathophysiology of severe falciparum malaria in man. Parasitology. 94:5s-76s.

24. Spriggs, D. R., and S. W. Yates. 1992. Cancer chemotherapy: experiences with TNF administration in humans. In Tumor Necrosis Factors. The Molecules and Their Emerging Role in Medicine. B. Beutler, editor. Raven Press, NY. 383 406.

25. Sprang, S., and M. J. Eck. 1992. The 3-D structure of TNF. In Tumor
Necrosis Factors. The Molecules and Their Emerging Role in Medicine. B. Beutler, editor. Raven Press, NY. 11-32.

26. Rathjen, D. A. A. Ferrante, and R. Aston. 1993. Differential effects of small tumour necrosis factor- $\alpha$ peptides on tumour cell cytotoxicity, neutrophil activation and endothelial cell procoagulant activity. Immunology. 80:293-299.

27. Atherton, E., H. D. Fox, C. J. Harkiss, R. C. Logan, S. Sheppard, and B. J. Williams. 1978. A mild procedure for solid phase peptide synthesis: use of fluorenylmethoxy carbonyl amino acids. J. Chem. Soc. Chem. Commun. 13:537540 .

28. Espevick, T., and J. Nissen-Myer. 1986. A highly sensitive cell line, WEHI-164, clone 13, for measuring cytotoxic factor/tumour necrosis factor from human monocytes. J. Immunol. Methods. 95:99-105.

29. Rathjen, D. A., K. Cowan, L. J. Furphy, and R. Aston. 1991. Antigenic structure of human tumour necrosis factor recognition of distinct regions of TNF by different tumour cell receptors. Mol. Immunol. 28:79-86.

30. Ferrante, A., and Y. H. Thong. 1982. Separation of mononuclear leukocytes from human blood by the one-step Hypaque-Ficoll method is dependent on blood column height. J. Immunol. Methods. 48:81-85.

31. Kutner, S., W. V. Breur, H. Ginsburg, S. B. Aley, and Z. I. Cabantchik. 1985. Characterization of permeation pathways in the plasma membrane of human erythrocytes infected with early stages of Plasmodium falciparum: association with parasite development. J. Cell. Physiol. 125:521-527.

32. Jaffe, E. A., R. L. Nachman, C. G. Becker, and C. R. Minick. 1973. Culture of human endothelial cells derived from umbilical veins. Identification by morphologic and immunologic criteria. J. Clin. Invest. 52:2745-2756.

33. Kumaratilake, L. M., A. Ferrante, E. J. Bates, and I. C. Kowanko. 1990 Augmentation of the human monocyte/macrophage chemiluminescence response during short-term exposure to interferon-gamma and tumour necrosis factor-alpha. Clin. Exp. Immunol. 80:257-262.

34. Kolodney, E. H., and R. A. Mumford. 1976. Human leukocyte acid hydrolase: characterization of eleven lysosomal enzymes and study of reaction conditions for their automated analysis. Clin. Chim. Acta. 70:247-257.

35. Gottlieb, C., K.-S. Lau, L. R. Wasserman, and V. Herbert. 1965. Rapid charcoal assay for intrinsic factor (IF), gastric juice unsaturated B12 binding capacity, antibody to IF and serum unsaturated B12 binding capacity. Blood. 25:875-883.

36. Berger, M., E. M. Wetzier, and R. S. Wallis. 1988. Tumor necrosis factor is the major monocyte product that increase complement receptor expression on mature human neutrophils. Blood. 71:151-158.

37. Perussia, B., M. Kobayashi, M. E. Ross, I. Anegon, and G. Trinchier 1987. Immune interferon enhances functional properties of human granulocytes: role of Fc receptors and effect of lymphotoxin, tumor necrosis factor, and granulocyte-macrophage colony stimulating factor. J. Immunol. 138:765-774.

38. Shalaby, M. R., B. B. Aggarwal, E. Rindeknecht, L. P. Svedersky, B. S. Finkle, and M. A. Palladino, Jr. 1985. Activation of human polymorphonuclear neutrophil functions by interferon- $\gamma$ and tumor necrosis factors. J. Immunol. 135:2069-2073.

39. Ockenhouse, C. F., M. Ho, N. N. Tandon, G. A. V. Seventer, S. Shaw, N. J. White, G. A. Jamieson, J. D. Chulay, and H. K. Webster. 1991. Molecular basis of sequestration in severe and uncomplicated Plasmodium falciparum malaria: differential adhesion of infected erythrocytes to CD36 and ICAM-1. J. Infect. Dis. 164:163-169.

40. Sherman, I. W., I. Crandall, and H. Smith. 1992. Membrane proteins involved in the adherence of Plasmodium falciparum-infected erythrocytes to the endothelium. Biol. Cell. 74:161-178. 